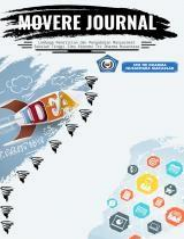

\title{
Pengaruh Motivasi Dan Lingkungan Kerja Terhadap Kinerja Karyawan Pada Bulog Kantor Cabang Makassar
}

\author{
Sekolah Tinggi Ilmu Ekonomi Tri Dharma Nusantara ${ }^{1,2,3}$ \\ Email : \\ Nunung_nurzanah134@gmail.com ${ }^{1}$ \\ iam.philosophia@gmail.com ${ }^{2}$ \\ aarijalnur@gmail.com ${ }^{3}$
}

Nunung Nurzanah ${ }^{1}$, Muh.Ilham Alimuddin², Andi Asad Ridjal Nur ${ }^{3}$

\begin{abstract}
Abstrak :
Penelitian ini bertujuan untuk mengetahui pengaruh Motivasi Kerja Dan Lingkungan Kerja terhadap Kinerja Karyawan pada Bulog Kantor Cabang Makassar. Jenis data yang digunakan dalam penelitian ini adalah data kualitatif dan kuantitatif. Sumber data yang digunakan berasal dari data primer dan juga sekunder. Metode analisis yang digunakan pada penelitian ini yaitu analisis deskriptif dan analisis statistik, analisis linear regresi berganda, koofisien korelasi, koofisien determinasi serja uji t, yang dioperasikan melalui program SPSS25, yaitu $\mathrm{Y}=2,308+0,291+0,605$. Adapun nilai koofisien korelasi $\mathrm{r}=$ 0,684 koofisien determinasi yaitu $r 2=0,469$ atau sebesar $46,9 \%$. Selanjutnya pada uji-t diperoleh hasil thitung $(2,059)<\mathrm{t}$ tabel $(1,694)$ untuk variabel motivasi dan thitung $(4,107)<\mathrm{t}$ tabel $(1,694)$ untuk variabel lingkungan kerja. Hingga dapat disimpulkan bahwa motivasi kerja dan lingkungan kerja berpengaruh secara simultan terhadap kinerja karyawan pada Bulog Kantor Cabang Makassar.
\end{abstract}

Kata kunci: Motivasi Kerja, Lingkungan Kerja, Kinerja Karyawan

\begin{abstract}
:
This study aims to determine the effect of work motivation and work environment on employee performance at Bulog Makassar Branch Office. The types of data used in this study are qualitative and quantitative data. Sources of data used come from primary and secondary data. The analytical method used in this research is descriptive analysis and statistical analysis, multiple linear regression analysis, correlation coefficient, coefficient of determination and t test, which is operated through the SPSS25 program, namely $Y=2,308+0,291+0,605$. The value of the correlation coefficient $r=0.684$ the coefficient of determination is $r 2=0.469$ or $46.9 \%$. Furthermore, the $t$-test results obtained tcount $(2,059)<$ ttable $(1,694)$ for motivation variable and tcount $(4,107)<$ ttable $(1,694)$ for work environment variable. So it can be concluded that work motivation and work environment have a simultaneous effect on employee performance at Bulog Makassar BranchOffice.
\end{abstract}

Keywords: Work Motivation, Work Environment, Employee Performance 


\section{PENDAHULUAN}

\section{A. Latar Belakang}

Suatu organisasi dibentuk untuk mencapai tujuan Bersama dari sebuah organisasi, dan untuk mcencapai tujuan tersebut secara efektif dibutuhkan manajegmen yang baik dan benar. Manajemen yang baik dan benar akan mampu membantu untuk mencapai tujuannya secara efektif. Manajemen sendiri yang meliputi proses perencanaan, pengorganisasian, koordinasi dan kontroling dari seluruh kegiatan organisasi sehingga bisa mencapai tujuan organisasi, jika semua kegiatan tersebut berjalan baik maka kegiatan pencapaian tujuan organisasi akan bisa berjalan secara efisien dan efektif.

Persaingan yang semakin meningkat dari waktu kewaktu, mendorong organisasiorganisasi ini berlomba-lomba untuk memperoleh keunggulan bersaing terutama dalam hal manajemen sumber daya manusia, terlebih sumber daya manusia yang paham akan teknologi, dan memiliki kreativitas tinggi. Keterangan di atas, dapat diketahui bahwa peranan manajemen sumber daya manusia sangat penting dalam sebuah atau organisasi, baik formal maupun informal.

Sumber daya manusia yang akan mampu memberikan kinerja yang baik dan menguntungkan bagi sebuah organisasi dalam pencapaian tujuan bersamanya terlebih dalam kondisi yang seperti saat ini, dimana perusahaan besar dengan segala kekayaan atau asset perusahaan yang dimilikinya pun juga ikut terkena dampak dari masa sulit ini.

Manajemen Sumber daya manusia (MSDM) memiliki peran yang vital dalam sebuah organisasi, baik itu organisasi formal maupun organisasi informal. Maka dari itu pengelolaan manajemen sumber daya manusia yang baik dan benar dalam suatu organisasi sangatlah penting, karena melihat bahwa manjemen sumber daya manusia ini sebagai roda penggerak dari sebuah organisasi.

Manajemen sumber daya manusia inilah yang akan berperan dalam keefektif dan efisienan dari sebuah organisai dalam mencapai tujuannya. Tanpa adanya sumber daya manusia yang baik atau berkualitas, sebuah organisasi akan sulit untuk bersaing dengan organisasi lainya. Terlebih di era globalisasi seperti saat ini yang mana sumber daya manusia yang berkualitas adalah asset yang sangat berharga bagi sebuah organisasi dalam menjalankan kegiatan organisasinya.

Karena pada kenyataanya, sumber daya manusia merupakan manusia yang di pekerjakan di dalam sebuah organisasi sebagai roda penggerak dari sebuah organisasi. Jika didalam sebuah organisasi yang memiliki teknologi yang canggih, modal besar dan sumber daya alam yang melimpah, namun tidak memiliki sumber daya manusia yang mampu mengelolanya maka semuanya akan menjadi hal yang tidak ada gunanya dan tujuan organisasi akan jadi hal mustahil untuk dicapai. Oleh karena itu sumber daya manusia yang bekualitas, memiliki kreativitas tinggi, dan memiliki daya saing memiliki peran yang sangat penting dalam sebuah perusahaan.

Dalam hal ini, sumber daya manusia memiliki berbagai keinginan yang ingin dipenuhinya. Keinginan-keinginan inilah yang memotivasi seorang karyawan untuk melakukan sesatu entah itu pekerjaanya ataupun hal-hal yang mana bisa membuatnya memenuhi keinginan-keinginanya tersebut. Setiap karyawan memiliki perbedaan motivasi dalam dirinya dalam hal pekerjaan maupun dalam sebuah pencapaian, ada yang ingin setiap apa yang ia lakukan mendapatkan sebuah pengakuan ataupun dalam hal-hal tertentu dari organisasi yang menaunginya.

Banyaknya keluhan dan ketidakpuasan dari karyawan atas kurangnya motivasi yang diterima yang secara tidak langsung dapat mempengaruhi kegiatan penyelesaian pekerjaan dari karyawan tersebut. Karyawan yang produktivitasnya kurang yang bisa saja diakibatkan karena kurangnya motivasi dari pihak organisasi/perusahaan. 
Melihat fenomena tersebut, maka seharusnya proses dalam meningkatkan kinerja tersebut pastinya terhambat. Oleh karena itu selain motivasi dari dalam diri sendiri, organisasi/perusahaan juga perlu memberikan motivasi juga, hal itu dilakukan agar motivasi dari karyawan ini semakin kuat dan hal itu akan berpengaruh dalam hal penyelesaian pekerjaan. Motivasi yang diberikan oleh organisasi kepada karyawan dapat meningkatkan kreativitas dan produktivitas karyawan dalam hal menyelesaiakan pekerjaanya. Sebagian orang berpendapat, motivasi itu timbul dikarenakan imbalan yang adil sesuai dengan apa yang telah dikerjakanya, meskipun terkadang juga hal tersebut tidak juga berpengaruh dengan cara seseorang tersebut menyelesaikan pekerjaanya.

Itulah mengapa dikatakan bahwa motivasi dari diri setiap orang itu berbeda, ada yang memang memiliki motivasi yang tinggi tanpa perlu dorongan dari luar, namun juga ada yang meskipun sudah ada tambahan dorongan dari luar masih saja tidak ada peningkatan motivasi dari dalam diri seseorang tersebut.

Selain motivasi kerja yang dapat mendorong kinerja seorang karyawan, lingkungan kerja juga merupakan suatu hal yang cukup penting, lingkungan dimana karyawan itu bekerja akan dapat mempengaruhi seorang karyawan dalam menyelesaikan tugas-tugas membuat karyawan menjadi semagat dalam bekerja dan menjadi lebih produktif, tanpa lingkungan kerja yang baik, karyawan akan mudah bosan dan tidak betah untuk berlama-lama berada didalam lingkungan tersebut.

Secara umum, lingkungan kerja adalah kehidupan fisik, sosial, dan psikologi dalam perusahaan yang mempengaruhi kinerja dan produktivitas karyawan. Selain berupa lingkungan yang menjadi tempat dimana karyawan bekerja, lingkungan kerja juga bisa menjadi faktor yang bisa meningkatkan kinerja karyawan atau bahkan menurunkan. Ketika seorang karyawan bekerja di lingkungan yang baik, maka ide, produktivitas, kinerja bisa meningkat, sebaliknya jika lingkungan kerja yang tidak baik dan tidak mendukung maka itu bisa menjadi salah satu faktor menurunnya kinerja karyawan.

Setelah mencermati fakta yang terjadi di lapangan dari penelitian terdahulu dengan pengaruh variabel independen pada variabel dependen yang positif. Maka penelitian ini mengambil judul "Pengaruh Motivasi dan Lingkungan Kerja terhadap Kinerja "Karyawan pada Bulog Kantor Cabang Makassar.

\section{B. Rumusan Masalah}

Berawal dari latar belakang yang telah dikemukakan sebelumnya, maka yang menjadi rumusan masalah pada penelitian ini adalah sebagai berikut:

1. Apakah motivasi berengaruh signifikan terhadap kinerja karyawan pada Bulog Kantor Cabang Makassar?

2. Apakah lingkungan kerja berpengaruh signifikan terhadap kinerja karyawan pada Bulog Kantor Cabang Makassar?

3. Apakah motivasi dan lingkungan kerja secara simultan berpengaruh signifikan terhadap kinerja pada Bulog Kantor Cabang Makassar?

\section{Tujuan dan Manfaat Penelitian \\ 1. Tujuan}

Adapun tujuan yang diharapkan pada penelitian ini berdasarkan rumusan masalah adalah sebagai berikut :

a. Untuk mengetahui pengaruh motivasi terhadap kinerja karyawan Bulog Kantor Cabang Makassar.

b. Untuk mengetahui pengaruh lingkungan kerja terhadap kinerja karyawan Bulog Kantor Cabang Makassar

c. Untuk mengetahui pengaruh motivasi dan lingkungan kerja terhadap kinerja karyawan Bulog Kantor Cabang Makassar. 


\section{Manfaat Penelitian}

Manfaat utama yang di harapkan dari ada penelitian ini:

a. Untuk institusi diharapkan penelitian ini bisa dijadikan sebagai pembanding untuk penelitian terdahulu ataupun sebagai referensi untuk penelitian berikutnya, terutama dalam manajemen sumber daya manusia.

b. Untuk penulis diharapkan agar penilitian ini bisa menjadi salah satu aspek institusi dalam menilai kemampuan mahasiswa/i selama perkuliahan dan juga menjadi salah satu syarat kelulusan. Sebagai bahan tambahan wawasan dan belajar dalam pengambilan keputusan dan kesimpulan.

\section{TINJAUAN PUSTAKA}

\section{A. Pengertian Motivasi}

Sebuah organisasi dalam berbagai kegiatannya untuk mencapai tujuan pasti dipengaruhi oleh kinerja dari para karyawannya, jika kinerja karyawannya baik maka bisa dipastikan kegiatan pencapaian tujuan itu akan bisa berjalan secara efektif dan efisien, dan untuk sebuah kinerja yang baik, karyawan harus punya motivasi yang baik untuk bekerja dan selain dari pihak karyawan motivasi dari luar diri si karyawan, misalnya motivasi yang berasal dari rekan kerja bahkan organisasi tempat si karyawan itu bernaung.

Motivasi inilah yang cenderung mendorong perilaku setiap individu dalam melakukan sesuatu, yang mana misalnya dalam menyelesaikan pekerjaanya. Motivasi dalam kamus besar Bahasa Indonesia disebutkan bahwa dorongan yang timbul pada diri seseorang secara sadar atau tidak sadar untuk melakukan suatu tidakan yang dengan tujuan tertentu.

Nawawi (2016:351) "mengatakan bahwa kata motivasi (motivation) kata dasarnya adalah motif (motive) yang berarti dorongan, sebab atau alasan seseorang melakukan sesuatu, dengan demikian motivasi berarti suatu kondisi yang mendorong atau menjadi sebab seseorang melakukan sesuatu perbuatan atau kegiatan yang berlangsung secara sadar". Berikut adalah pengertian motivasi menurut para ahli:

a. Sutrisno (2019:146) "motivasi adalah suatu faktor yang mendorong seseorang untuk melakukan aktivitas tertentu, oleh karena itu motivasi sering kali diartikan pula sebagai faktor pendorong perilaku seseorang".

b. Kasmir (2019:190) "motivasi merupakan dorongan bagi seseorang untuk melakukan pekerjaan, jika karyawan memiliki dorongan yang kuat dari dalam dirinya atau dari luar dirinya, maka karyawan akan terangsang atau terdorong untuk melakukan sesuatu dengan baik".

Adapun yang perlu diperhatikan seorang pemimpin dalam memberikan motivasi agar berhasil menurut Sutrisno (2019:147) adalah sebagai berikut:

a. Memahami perilaku bawahanya.

b. Harus berbuat dan berperilaku realistis.

c. Tingkat kebutuhan setiap orang berbeda.

d. Pemberian motivasi harus mengacu pada orang.

e. Harus dapat memberi keteladanan.

Untuk itu mereka dituntut dapat menggunakan kealiannya :

a. Menciptakan iklim kerja yang menyenangkan.

b. Memberikan penghargaan dan pujian bagi yang berprestasi.

c. Membagi tugas sesuai dengan kemampuan.

d. Memberikan umpan balik tentang hasil pekerjaan.

e. Memberi kesempatan bawahan untuk maju dan berkreatifitas.

\section{B. Pengertian Lingkungan Kerja}

Lingkungan kerja yang kondusif pasti akan mampu membuat para karyawan merasa aman dan nyaman dalam menyelesaikan 
pekerjaannya. Lingkungan kerja sendiri adalah tempat dimana seorang karyawan atau pekerja menyelesaikan pekerjaan yang meliputi sarana prasarana dan juga kondisi tempat bekerja itu sendiri, seperti hubungan antara karyawan biasa hingga dengan atasan di perusahaan tersebut yang bisa mempegaruhi kondisi pekerja dalam menyelesaikan tugasnya.
Menurut
Kasmir
(2019:192)

"lingkungan kerja merupakan suasana atau kondisi di sekitar lokasi tempat bekerja, lingkungan kerja dapat berupa ruangan, layout, sarana dan prasarana serta hubungan kerja dengan sesama rekan kerja". Berikut

Lingkungan kerja menurut para ahli:

Sedarmayanti (2017:25) "mengatakan bahwa lingkungan kerja merupakan keseluruhan alat perkakas dan bahan yang di hadapi, lingkungan sekitarnya dimana seseorang bekerja, metode kerjanya, serta pengaturan kerjanya baik sebagai perseorangan maupun sebagai kelompok".

Afandi (2016:51) "lingkungan kerja adalah sesuatu yang ada di lingkungan para pekerja yang dapat mempengaruhi dirinya dalam menjalankan tugas seperti temperatur, kelembapan, ventilasi, penerangan, kegaduhan, kebersihan tempat kerja dan memadai tidaknya alat-alat perlengkapan kerja".

Sunyoto (2015:38) "lingkungan kerja merupakan komponen yang sangat penting ketika karyawan melakukan aktivitas bekerja, dengan memperhatikan lingkungan kerja yang baik atau menciptakan kondisi kerja yang mampu memberikan motivasi untuk bekerja, maka akan membawa pengaruh terhadap kinerja karyawan dalam bekerja".

\section{Pengertian kinerja}

Dalam sebuah organisasi/perusahaan, kinerja adalah salah saru hal yang paling penting, karena kinerja tersebutlah yang berpengaruh langsung terhapap tercapai atau tidaknya tujuan ataupun perencanaan sebuah organisasi/perusahaan. Kinerja itu sendiri adalah perilaku seorang individu/karyawan dalam menyelesaikan pekerjaannya dan dari hasil penilaian kinerja inilah perusahaan dapat melihat sampai dimana kemampuan seorang karyawan.

Menurut Kasmir (2019:184) "kinerja adalah hasil kerja dan perilaku kerja. Jika kinerja berdasarkan hasil, maka yang dilihat adalah jumlah kualitas maupun kuantitas yang dihasilkan oleh seseorang. Misalnya kemampuan seseorang menjual suatu barang yang sudah ditargetkan". Berikut adalah kinerja menurut para ahli:

a. Sinambela (2018:480) "kinerja didefinisikan sebagai kemampuan pegawai dalam melakukan suatu keahlian tertentu, kinerja pegawai sangatlah penting, sebab dengan kinerja ini akan diketahui seberapa jauh kemampuan mereka dalam melaksanakan tugas-tugas yang di bebankan kepadanya".

b. Ivancevich, Konopaske, dan Matteson dalam Busro (2020:87-88) menyatakan bahwa kinerja menunjukan kemampuan dan keterampilan pekerja. Pendapat ini lebih menekankan kepada kemampuan dan kreadibilitas yang dimiliki seseorang.

Dibagian lain dijelaskan tentang kontribusi yang di berikan kinerja terhadap organisasi antara lain yaitu:

a. Kuantitas keluaran (semakin banyak semakin baik)

b. Kualitas keluaran (semakin berkualitas semakin baik)

c. Jangka waktu yang dibutuhkan semakin singkat

d. Kehadiran ditempat kerja

e. Sikap kooperatif di dalam organisasi

\section{Hubungan Lingkungan Kerja terhadap Kinerja}

Seorang karyawan akan menunjukan hasil kerja yang maksimal bila didukung oleh sarana dan prasarana yang ada dan juga lingkungan yang mendukung. Seperti yang dikatakan oleh Sutrisno (2019:118-119) "lingkungan kerja yang buruk, kotor, gelap, pengap, lembab, dan 
sebagainya akan menimbulkan cepat lelah dan menurunkan kreativitas". Dengan demikian, dapat dikatakan bahwa lingkungan kerja dan kinerja memiliki hubungan yang berkaitan satu sama lain hal tersebut terlihat jelas dari penjelasan para ahli.

$$
\text { Wibowo (2014:330) "menyebutkan }
$$

bahwa motivasi dapat dipastikan mempengaruhi kinerja, walaupun bukan satusatunya yang membentuk kinerja". Menurut Kasmir (2019:190-192) "faktor-faktor yang mempengaruhi kinerja, diantaranya ialah kemampuan dan keahlian, pengetahuan, kepribadian, motivasi kerja, gaya kepemimpinan, kepuasan kerja, lingkungan kerja dan juga komitmen dari karyawan itu sendiri"

Dari pernyataan-pernyataan diatas dapat diambil kesimpulan bahwa motivasi kerja dan lingkungan kerja memiliki hubungan yang berkaitan satu sama lain, motivasi kerja yang baik didukung lingkungan kerja yang mendukung akan menghasilkan kinerja yang baik pula.

\section{E. Hipoteis}

Berdasarkan hasil uraian dan hasil penjelasan di atas, maka peneliti mengajukan hipotesis sebgai berikut:

H1 : Motivasi berpengaruh signifikan terhadap kinerja karyawan Bulog Kantor Cabang Makassar.

$\mathrm{H} 2$ : Lingkungan kerja berpengaruh signifikan terhadap kinerja karyawan Bulog Kantor Cabang Makassar

H3 : Motivasi dan lingkungan kerja berpengaruh secara simultan terhadap kinerja karyawan Bulog Kantor Cabang Makassar.

\section{METODE PENELITIAN}

\section{A. Lokasi dan Waktu penelitian}

Penelitian akan dilaksanakan pada Bulog kantor Cabang Makassar yang berlokasi di jalan Urip Sumoharjo no. 42, Panaikang, kec Panakukkang, Kota Makassar, Sulawesi Selatan. Penelitian ini akan dilakukan dalam kurun waktu kurang lebih 2 bulan lamanya. Penelitian ini dimulai pada 17 November 2020 hingga 15 Januari 2021.

1. Jenis dan Sumber Data

Penelitian ini merupakan suatu kegiatan yang dilakukan secra terencana dan sistematis untuk mendapatkan jawaban pemecahan masalah-masalah tertentu yang telah ditetapkan, maka jenis data yang digunakan pada penelitian ini adalah sebagai berikut:

a. Data kualitatif

Data kualitatif adalah sebuah data yang diperoleh oleh peneliti dari hasil wawancara, observasi, dan data penunjang lainnya yang diperoleh dari karyawan Bulog Kantor Cabang Makassar.

b. Data kuantitatif

Data kuantitatif adalah sebuah data yang diperoleh oleh peneliti dengan membagikan kuesioner, dan hasil analisa dari data statistik yang diperoleh dari karyawan Bulog Kantor Cabang Makassar.

\section{B. Sumber Data}

Berdasarkan sumber yang telah di dapat, data yang akan digunakan berasal dari data sekunder yang diperoleh dari laporan-laporan atau data tertulis yang berasal dari perusahaan yang akan diteliti.

1. Data Primer

Data primer adalah data yang secara langsung diperoleh dari perusahaan yang merupkan hasil dari pembagian kuesioner dan juga pegamatan saat, melakukan penelitian. Data ini bersifat data kualitatif yang berisikan atau berhubungan dengan pengaruh motivasi dan lingkungan kerja terhadap kinerja karyawan. Dalam penelitian ini data primer didapatkan dengan menyebar kuisioner kepada karyawan Bulog Kantor Cabang Makassar.

2. Data Sekunder

Data sekunder ini diperoleh oleh penulis dari berkas ataupun laporan-laporan tertulis serta informasi tentang keadaan perusahaan. 


\section{Metode pengumpulan data}

Adapun metode pengumpulan data yang dilakukan pada penelitian ini adalah sebagai berikut:

1. Penelitian Pustaka, yaitu penelitian yang dilakukan melalui penelaan buku-buku literatur yang relevan dengan judul dan masalah yang diteliti.

2. Penelitian Lapangan, yaitu penelitian yang dilakukan dengan cara kunjungan langsung pada objek penelitian. Untuk mendapatan data lapangan, yang ril dan dapat digunakan Teknik sebagai berikut :

a. Observasi, Salah satu tehnik yang dapat digunakan untuk mengatahui atau menyelidiki tingkah laku non verbal yakni dengan menggunakan tehnik observasi. Menurut Sugiyono (2018:229) "observasi merupakan tehnik pengumpulan data yang mempunyai ciri yang spesifik bila dibangdingkan dengan tehnik lainnya"

b. Wawancara, Wawancara menjadi salah satu tehnik yang digunakan untuk mengumpulkan data penelitian.

c. Dokumentasi, Menurut Sugiyono (2018:476) "dokumentasi adalah suatu cara yang digunakan untuk memperoleh data dan informasi dalam bentuk buku, arsip, dokumen, tulisan angka dan gambar yang berupa laporan serta keterangan yang dapat mendukung penelitian"

d. Kuisioner, Sugiyono (2017:142) "menyatakan angket atau kuesioner merupakan tehnik pengumpulan data yang dilakukan dengan cara memberi seperangkat pertanyaan atau peryataan tertulis kepada responden untuk dijawab nya".

\section{Populasi dan Sampel}

\section{Populasi}

Sugiyono (2017:80) menyatakan bahwa populasi adalah wilayah generalisasi yang terdiri atas objek-objek yang mempunyai kualitas dan karakteristik tertentu yang ditetapkan oleh peneliti untuk dipelajari dan kemudian ditarik kesimpulan.

Pada penelitian ini, jumlah populasi sebanyak 49 orang yakni seluruh karyawan yang bekerja pada Bulog Kantor Cabang Makassar.

\section{Sampel}

Menurut Sugiyono (2017:118) "Sampel merupakan bagian dari jumlah dari karakteristik yang dimiliki oleh populasi tersebut". Pada penelitian ini menggunakan metode random sampling dimana keseluruhan populasi berkesempatan menjadi sampel dan responden yang diambil sebanyak 35 orang yang ada pada Bulog Kantor Cabang Makassar.

\section{Metode Analisis Data}

a. Analisis Statistik

b. Uji Validitas, dan Uji Reliabilitas

c. Analisis Regresi Linear Berganda

Analisis regresi liniear berganda ini bertujuan untuk mengetahui ada tidaknya suatu hubungan antara variabel X1 (Motivasi) dan $\mathrm{X} 2$ (Lingkungan Kerja) dengan Y (Kinerja Karyawan) dimana ketiga variabel tersebut motivasi dan lingkungan kerja sebagai variabel bebas, dan kinerja karyawan sebagai variabel tidak bebas. Analisis regresi ini dinyatakan dengan persamaan sebagai berikut :

$\mathrm{Y}=\alpha+\mathrm{b} 1 \mathrm{X} 1+\mathrm{b} 2 \mathrm{X} 2$

Keterangan:

$\mathrm{Y} \quad=$ Kinerja Karyawan

$\mathrm{X} 1=$ Motivasi

X2 = Lingkungan Kerja

a $=$ Konstanta

b1,b2 = Koefisien regresi

Analisis Korelasi @

Koefisien korelasi digunakan untuk mengukur keeratan hubungan motivasi dan lingkungan kerja terhadap kinerja karyawan. 
Analisis korelasi pada penelitian ini didapatkan melalui proses komputerisasi SPSS 20.

Koefisien korelasi (r) bertujuan untuk mengetahui seberapa terkaitnya dan keterkaitannya disebut dengan nilai signifikan Tabel 1 : Pedoman interprestasi kriteria koefisien korelasi (r)

\begin{tabular}{|c|c|c|}
\hline NO & Interval $(\%)$ & Kriteria \\
\hline 1 & $0,00-0,199$ & Sangat rendah \\
\hline 2 & $0,20-0,399$ & Rendah \\
\hline 3 & $0,40-0,599$ & Sedang \\
\hline 4 & $0,60-0,799$ & Kuat \\
\hline 5 & $0,80-1,000$ & Sangat Kuat \\
\hline
\end{tabular}

Sumber: Sugiyono (2017:184)

a. Koefisien Determinasi (R2) Setelah diketahui korelasinya, kemudian koefisien determinasi digunakan untuk mengetahui seberapa kuat pengaruh kedua variable.

b. Uji parsial, Uji parsial (t) adalah sesuatu yang dapat di ukur dengan kasat mata Uji Kemudian untuk menguji hipotesis bahwa terdapat pengaruh positif dan signifikan antara motivasi dan lingkungan kerja terhadap kinerja karyawan di Bulog kantor Cabang Makassar, dilakukan perbandingan antara t-hitung dengan t-tabel dengan taraf nyata $0,05(5 \%)$.

c. Uji F

Bertujuan untuk menguji signifikansi pengaruh Motivasi Kerja dan Lingkungan Kerja terhadap Kinerja karyawan pada Bulog kantor Cabang Makassar secara simultan. Langkah-langkah pengujian hipotesis sebagai berikut:

1. Rumuskan hipotesis:

H0: $\beta 1=\beta 2=0$ artinya tidak ada pengaruh signifikan secara simultan antara Motivasi dan Lingkungan Kerja terhadap kinerja karyawan pada Bulog Kantor Cabang Makassar.

Ha:Salah satu $\beta i \neq 0(i=1$ dan 2$)$ artinya ada pengaruh signifikan secara seperti yang kemudian dapat dilihat pada tabel 4.

Berikut dibawah ini tabelpedoman interprestasi kriteria koefisien korelasi (r) 
IV. HASIL DAN PEMBAHASAN

A. Analisis Karakteristik Responden
1. Berdasarkan Jenis Kelamin

Pada begian ini penelitian akan mengukur karakteristik responden berdasarkan jenis kelamin.

Tabel 2: Karakteristik responden berdasarkan jenis kelamin

\begin{tabular}{|c|c|c|c|}
\hline No & Jenis kelamin & Jumlah responden (orang) & Persentase (\%) \\
\hline \multirow{2}{*}{1} & Laki-laki & 24 & 68,58 \\
2 & Perempuan & 11 & 31,42 \\
\hline \multicolumn{2}{|c|}{ Total reponden } & 35 & 100 \\
\hline
\end{tabular}

Sumber: Data diolah, 2021

Pada tabel diatas, menggambarkan bahwa dalam penelitian ini jumlah responden laki-laki memiliki responden sebanyak 24 orang dengan persentase sebesar $68,58 \%$ dan responden perempuan sebanyak 11 orang dengan persentase sebesar $31,42 \%$. Sehingga dapat disimpulkan bahwa responden laki-laki sangat dominan. Hal tersebut sesuai dengan kondisi dan beban kerja pada Bulog Kantor Cabang Makassar.
2. Berdasarkan Tingkat usia

Faktor usia merupakan salah satu identitas guna menjadi petunjuk untuk mengetahui kemampuan fisik dan kemampuan daya fikir responden.

Berikut dilaporkan hasil distribusi angket usia responden di Bulog Kantor Cabang Makassar.

Tabel 3: Kararakteristik reponden berdasarkan usia

\begin{tabular}{|c|c|c|c|}
\hline No & Usia & Responden & Persentase (\%) \\
\hline 1 & $25-35$ & 18 & 51,43 \\
2 & $36-45$ & 4 & 11,43 \\
3 & $46-55$ & 13 & 37,11 \\
\hline & Jumlah & 35 & 100 \\
\hline
\end{tabular}

Sumber: Data diolah,2021

Berdasarkan tabel 6 di atas menunjukan bahwa usia responden variatif antara usia 2535 tahun terdapat 18 responden dengan persentase $51,43 \%$, pada usia 36-45 tahun terdapat 4 responden dengan persentase $11,43 \%$, pada usia 46-55 tahun terdapat 13 responden dengan persentase $37-11 \%$. Jumlah responden yang bekerja pada Bulog Kancap Makassar berdasarkan usia rentang 25-35 tahun adalah terbanyak dengan jumlah 18 responden, hal ini disebabkan karena dianggap karyawan yang berusia kisaran tersebut lebih produktif.

3. Berdasarkan Jenjang Pendidikan

Tidak hanya jenis kelamin dan usia, penelitian ini juga mengumpulkan data terkait dengan jenjang pendidikan responden pada Bulog Kancap Makassar. Karyawan pada Bulog Kantor Cabang Makassar terdiri dari tingkat SMA/SMK, Diploma 3, hingga Strata 
Satu (S1) adapun rincianya adalah sebagai berikut.

Tabel 4: Karakteristik reponden berdasarkan pendidikan.

\begin{tabular}{|c|c|c|c|}
\hline No & Pendidikan & Reponden & Persentase (\%) \\
\hline $\begin{array}{l}1 \\
2 \\
3\end{array}$ & $\begin{array}{c}\text { SMA/SMK } \\
\text { D3 } \\
\text { S1 }\end{array}$ & $\begin{array}{c}13 \\
3 \\
19\end{array}$ & $\begin{array}{c}37,25 \\
8,57 \\
54,28\end{array}$ \\
\hline \multicolumn{2}{|c|}{ Jumlah } & 35 & 100 \\
\hline
\end{tabular}

Sumber : Data diolah, 2021

Bedasarkan tabel 7 diatas pendidikan SMA/SMK terdapat 13 responden dengan persentase $37,15 \%$, D3 terdapat 3 responden dengan persentase $8,57 \%$, dan S1 terdapat 19 responden dengan persentase 54,28\%. Dari tabel diatas dapat dilihat bahwa tingkat Pendidikan seseorang mempengaruhi kemampuan seseorang dalam mencapai kinerja yang optimal.
4. Berdasarkan Masa kerja

Masa kerja adalah waktu/lamanya seseorang berkerja atau mengadi pada suatu perusahaan. Masa kerja yang relatif lama, biasanya karyawan tersebut cukup cakap dalam mengelola dan melaksanakan bebean pekerjaan yang memiliki tanggung jawab yang besar. Untuk itu, berikut karakteristik responden berdasarkan masa kerja pada Bulog Kantor Cabang Makassar.

Tabel 85 Karakteristik responden berdasarkan masa kerja

\begin{tabular}{|c|c|c|c|}
\hline No & Masa Kerja & Responden & Persentase (\%) \\
\hline 1 & $1-10$ & 16 & 45,72 \\
2 & $11-20$ & 12 & 34,28 \\
\hline 3 & $21-30$ & 7 & 20 \\
\hline \multicolumn{2}{|l|}{ Jumlah } & 35 & 100 \\
\hline
\end{tabular}

Sumber : Data diolah,2021

Berdasarkan tabel 8 diatas menunjukan bahwa antara 1-10 tahun terdapat 16 responden dengan persentase $45,72 \%$. Pada 11-20 tahun terdapat 12 responden juga dengan persentase yang sama yaitu $34,28 \%$, dan pada 21-30 tahun terdapat 7 reponden dengan persentase $20 \%$. Pada pembahasan berdasarkan usia karyawan dijelaskan bahwa Bulog Kantor Cabang Makassar, berkaitan dengan lamanya karyawan bekerja pada perusahaan memiliki tingkat masa kerja yang berbeda-beda. Dengan demikian responden yang mempunyai masa kerja terbanyak ada pada 1-10 tahun yaitu sebanyak 16 reponden dengan persentase yang sama yaitu $45,72 \%$.

\section{B. Metode Analisis Data}

\section{Uji Validitas}

Uji validitas digunakan untuk mengetahui valid atau sahnya sebuah kuesioner. Dalam penelitian ini, uji validitas dilakukan dengan menghitung koefisien kolerasi antara skor total dengan skor itemnya. Biasanya, korelasi yang 
digunakan ialah Pearson correlation, antara setiap skor indikator dan total skor variabel. Validitas adalah suatu ukuran yang menunjukan tingkat kevaliditan sebuah data atau instrument. suatu data dikatakan valid, apa bila bisa atau mampu mengukur apa yang harus dan hendaknya diukur. Apabila
Corelation ( $\mathrm{r}$ hitung) $>\mathrm{r}$ table maka skor item pernyataan tersebut dinyatakan valid sebaliknya maka item tersebut dinyatakan tidak valid. Dalam penelitian ini uji validitas dilakukan dengan bantuan software SPSS 25.0.0.0 tabel dibawah ini hasil dari uji validitas:

Tabel 6: Uji Validitas

\begin{tabular}{|c|c|c|c|c|c|}
\hline Variabel & Indikator & r Hitung & r Tabel & Signifikan & Keterangan \\
\hline \multirow{4}{*}{$\begin{array}{c}\text { Motivasi } \\
\text { (X1) }\end{array}$} & $\mathrm{X} 1.1$ & 0,704 & 0,3338 & 0,000 & Valid \\
\hline & X1.2 & 0,498 & 0,3338 & 0,002 & Valid \\
\hline & $\mathrm{X} 1.3$ & 0,345 & 0,3338 & 0,043 & Valid \\
\hline & $\mathrm{X} 1.4$ & 0,568 & 0,3338 & 0,000 & Valid \\
\hline \multirow{16}{*}{$\begin{array}{c}\text { Lingkungan } \\
\text { Kerja(X2) }\end{array}$} & $\mathrm{X} 1.5$ & 0,488 & 0,3338 & 0,003 & Valid \\
\hline & $\mathrm{X} 1.6$ & 0,535 & 0,3338 & 0,001 & Valid \\
\hline & X1.7 & 0,686 & 0,3338 & 0,000 & Valid \\
\hline & $\mathrm{X} 1.8$ & 0,595 & 0,3338 & 0,000 & Valid \\
\hline & X1.9 & 0,477 & 0,3338 & 0,004 & Valid \\
\hline & $\mathrm{X} 1.10$ & 0,431 & 0,3338 & 0,010 & Valid \\
\hline & $\mathrm{X} 2.1$ & 0,531 & 0,3338 & 0,001 & Valid \\
\hline & $\mathrm{X} 2.2$ & 0,514 & 0,3338 & 0,000 & Valid \\
\hline & $\mathrm{X} 2.3$ & 0,556 & 0,3338 & 0,000 & Valid \\
\hline & $\mathrm{X} 2.4$ & 0,604 & 0,3338 & 0,002 & Valid \\
\hline & $\mathrm{X} 2.5$ & 0,338 & 0,3338 & 0,000 & Valid \\
\hline & $\mathrm{X} 2.6$ & 0,337 & 0,3338 & 0,040 & Valid \\
\hline & $\mathrm{X} 2.7$ & 0,395 & 0,3338 & 0,048 & Valid \\
\hline & $\mathrm{X} 2.8$ & 0,361 & 0,3338 & 0,019 & Valid \\
\hline & X2.9 & 0,472 & 0,3338 & 0,004 & Valid \\
\hline & X2.10 & 0,662 & 0,3338 & 0,000 & Valid \\
\hline \multirow{5}{*}{$\begin{array}{l}\text { Kinerja } \\
(\mathrm{Y})\end{array}$} & $\mathrm{Y} 1$ & 0,396 & 0,3338 & 0,019 & Valid \\
\hline & $\mathrm{Y} 2$ & 0,356 & 0,3338 & 0,036 & Valid \\
\hline & $\mathrm{Y} 3$ & 0,394 & 0,3338 & 0,017 & Valid \\
\hline & Y4 & 0,527 & 0,3338 & 0,001 & Valid \\
\hline & Y5 & 0,628 & 0,3338 & 0,000 & Valid \\
\hline
\end{tabular}




\begin{tabular}{|c|c|c|c|c|c|}
\hline & Y6 & 0,518 & 0,3338 & 0,001 & Valid \\
\cline { 2 - 6 } & Y7 & 0,461 & 0,3338 & 0,005 & Valid \\
\cline { 2 - 6 } & Y8 & 0,493 & 0,3338 & 0,002 & Valid \\
\cline { 2 - 6 } & Y9 & 0,755 & 0,3338 & 0,000 & Valid \\
\cline { 2 - 6 } & Y10 & 0,741 & 0,3338 & 0,000 & Valid \\
\hline
\end{tabular}

Sumber: Data diolah, 2021

Berdasarkan tabel yang ada diatas dapat dinyatakan bahwa hasil perhitungan $r$ hitung semua lebih besar yaitu $\mathrm{df}=(\mathrm{n}-2)$ yaitu 33$2=31$, dan $\alpha=5 \%(0,05)$ sebesar 0,333 dan nilai signifikan $<0,05$ hal ini membuktikan bahwa berarti seluruh pernyataan pada variabel diatas adalah valid

2. Uji Reabilitas

Uji reabilitas dilakukan untuk mengetahui apakah instumen yang digunakan akan tetap konsisten apabila dilakukan uji berkali-kali. Uji reabilitas yang digunakan dalam penelitian ini ialah Cronbach's alpha. Uji reabilitas ini dilakukan untuk mengukur suatu kuesioner yang merupkan indikator dari variabel. Suatu data atau instrument dikatakan reliabel atau konsisten apabila reabilitas lebih dari 0,6 dengan menggunakan tehnik Cronbach's alpa, dan uji reabilitas yang digunakan pada penelitian ini menggunakan Software SPSS 25.0.0.0, dan dibawah ini merupakan hasil dari uji reabilitas:

Tabel 7: Tabel Uji Realibilitas

\begin{tabular}{|l|c|c|c|}
\hline \multicolumn{1}{|c|}{ Variabel } & Cronbach's Alpha & instrumen & Keterangan \\
\hline Motivasi Kerja (X1) & 0,719 & 0,6 & Realiabel \\
\hline Lingkungan Kerja (X2) & 0,613 & 0,6 & Realiabel \\
\hline Kinerja (Y) & 0,698 & 0,6 & Realiabel \\
\hline
\end{tabular}

Sumber: Data diolah, 2021

Berdasarkan tabel hasil uji yang ada diatas, dapat disimpulkan bahwa variabel-variabel diatas, yaitu Motivasi (X1), Lingkungan Kerja (X2), dan Kinerja (Y), dapat dikatakan semuanya telah reliabel. Dengan demikian bahwa, item-item ini dapat di aplikasikan untuk penelitian selanjutnya. Ini mengidentifikasikan bahwa semua item telah memenuhi satandar kelayakan untuk selanjutnya dapat di aplikasikan langsung terhadapp responden.

\section{Uji Analisis Liniear Berganda}

Dalam penelitian ini untuk mengetahui besarnya koofisien regresi apakah variabel
Motivasi (X1), Lingkungan Kerja (X2) memiliki pengaruh yang signifikan terhadap Kinerja (Y) karyawan pafda Kantor Bulog Cabang Makassar. Persamaaan regresi linear yang dihasilkan nantinya akan dilakukan pengujian koofisien masing-masing.

Analisis regresi liniear berganda yang di gunakan dalam penelitian ini menggunakan aplikasi Software SPSS 25.0.0.0 dan bentuk persamaanya adalah:

$\mathrm{Y}=\alpha+\mathrm{b} 1 \mathrm{X} 1+\mathrm{b} 2 \mathrm{X} 2$

Maka berdasarkan analisis yang telah dilakukan dengan menggunakan program SPSS dapat disajikan persamaan regresi linear bergada sebagai berikut: 
Tabel 8: Analisis linear berganda

\begin{tabular}{|c|c|c|c|c|c|c|}
\hline \multicolumn{7}{|c|}{ Coefficients $^{\mathbf{a}}$} \\
\hline & \multirow{2}{*}{ Model } & \multicolumn{2}{|c|}{ Unstandardized Coefficients } & Standardized & \multirow{2}{*}{$\mathrm{t}$} & \multirow{2}{*}{ Sig. } \\
\hline & & B & Std. Error & Beta & & \\
\hline \multirow[t]{3}{*}{1} & (Constant) & 2,308 & 7,702 & & 0,300 & 0,766 \\
\hline & Motivasi Kerja & 0,291 & 0,142 & 0,277 & 2,059 & 0,048 \\
\hline & Lingkungan Kerja & 0,605 & 0,147 & 0,552 & 4,107 & 0,000 \\
\hline
\end{tabular}

Sumber : Output SPSS25

Berdasarkan tabel pengujian diatas, maka diperoleh persamaan regresi linear berganda sebagai berikut:

$\mathrm{Y}=\mathrm{a}+\mathrm{b} 1 \mathrm{X} 1+\mathrm{b} 2 \mathrm{X} 2$

$\mathrm{Y}=2,308+0,291+0,605$

Berikut adalah uraian persamaan regresi linear berganda, dari tabel diatas:

a. Tanpa adanya variabel Motivasi (X1) dan Lingkungan Kerja (X2), maka Kinerja (Y) tetap sebesar 2,308.

b. Koofisien b1=0,291 menunjukan peningkatan 1 skor Motivasi (X1), akan meningkatkan kinerja dari seorang karyawan sebesar 0,291 dengan asumsi setiap variabel bebas lainnya bernilai konstan. Koofisien bernilai positif artinya ada pengaruh antara Motivasi dan Kinerja, artinya semakin tinggi Motivasi (X1) maka akan meningkatkan Kinerja (Y). c. Koofisien b2=0,605 menunjukan peningkatan 1 skor Lingkungan Kerja (X2), akan meningkatkan kinerja karyawan dengan asumsi setiap variabel bebas bernilai konstan, artinya terjadi pengaruh antara Lingkungan Kerja (X2), dan Kinerja (Y), semakin Lingkungan Kerja (X2) ditingkatkan kualitasnya maka akan terjadi peningkatan terhadap Kinerja.

4. Uji Koofisien Kolerasi (R)

Uji koofisien kolerasi ini digunakan untuk mengukur keeratan hubungan antara variabel Motivasi (X1), Lingkungan Kerja (X2), pengaruhnya terhadap Kinerja (Y) karyawan analisis koofisien kolerasi ini menggunakan aplikasi SPSS 25. Dibawah ini adalah hasil dari uji koofisien korelasi penelitian ini.

Tabel 9: uji Koofisien Korelasi

\begin{tabular}{|c|c|c|c|c|}
\hline \multicolumn{5}{|c|}{ Model Summary $^{\mathbf{b}}$} \\
\hline Model & $\mathrm{R}$ & R Square & Adjusted R Square & Std. Error of the Estimate \\
\hline 1 & $.684^{\mathrm{a}}$ & 0,469 & 0,435 & 2,393 \\
\hline \multicolumn{4}{|l}{ a. Predictors: (Constant), Lingkungan Kerja, Motivasi Kerja } \\
\hline
\end{tabular}

Sumber: Output SPSS25

Berdasarkan tabel hasil uji diatas dapat diketahui nilai $\mathrm{R}$ atau koofisien korelasi atau bearan hubungan ialah 0,684 atau 68,4\% yang termasulk dalam kategori hubungan yang kuat, maka dapat disimpulkan bahwa Motivasi (X1), dan Lingkungan Kerja (X2), memiliki pengaruh yang kuat terhadap Kinerja (Y) karyawan pada Bulog Kantor Cabang Makassar. 
5. Uji Koofisien Determinasi (R2)

Uji koofisien determinasi

digunakan untuk mengukur seberapa jauh kemampuan variabel independen dalam mempengaruhi variabel dependen. Nilai R2 yang semakin mendekati 1 , berarti tiap variabel independen hampir semua memberikan informasi yang dibutuhkan untuk memprediksi variabel independent. Koofisien determinasi yang digunakan adalah nilai $\mathrm{R}$, dan nilai $\mathrm{R}$ ini dapat naik dan juga turun, apa bila ada penambahan variabel pada model yang ada.

Tabel 10: Uji Koofisien Determinasi

\begin{tabular}{|c|c|c|c|c|}
\hline \multicolumn{5}{|c|}{ Model Summary $^{\mathbf{b}}$} \\
\hline Model & $\mathrm{R}$ & R Square & Adjusted R Square & Std. Error of the Estimate \\
\hline 1 & $.684^{\mathrm{a}}$ & 0,469 & 0,435 & 2,393 \\
\hline
\end{tabular}

Sumber: Output SPSS25

Berdasarkan tabel yang ada diatas, diketahui nilai (R) adalah 0,469 atau $46,9 \%$. Artinya ada hubungan searah yang kuat antara variabel independen Motivasi (X1), Lingkungan Kerja (X2), dengan variabel Kinerja (Y) karyawan pada Bulog Kantor Cabang Makassar. Berarti, jika variabel Motivasi (X1), dan Lingkungan Kerja (X2) ditingkatkan, maka kinerja karyawan pada Bulog Kantor Cabang Makassar akan meningkat, dan begitupun sebaliknya

Persentase pengaruh variabel independen terhadap variabel dependen yang ditunjukan koofisien determinasi simultan ( $\mathrm{R}$ Square) adalah sebesar 0,469. Hal ini berarti bahwa naik dan turunnya variabel dependen yaitu Kinerja (Y) karyawan Bulog Kantor cabang Tabel 11: Uji t makassar, dipengaruhi oleh variabel independen Motivasi (X1), Lingkungan Kerja (X2) sebesar $46,9 \%$ sedangkan sisanya $53,1 \%$ dijelaskan oleh variabel lain diluar penelitian ini.

\section{Uji t}

Uji $\mathrm{t}$ ini di lakukan untuk mengetahui secara parsial variabel independent kepada variabel dependen. Uji t dilakukan dengan cara membandingkan nilai $\mathrm{t}$ hitung dengan $\mathrm{t}$ tabel dengan tingkat kesalahan yaitu 5\% dengan pengujian dua sisi yaitu 1,694. Apabila t hitung $>\mathrm{t}$ tabel maka dapat disimpulkan bahwa variabel tersebut memiliki pengaruh signifikan.

\begin{tabular}{|c|c|c|c|c|c|c|}
\hline \multicolumn{2}{|c|}{} & \multicolumn{6}{|c|}{$\begin{array}{c}\text { Unstandardized } \\
\text { Coefficients }\end{array}$} & $\begin{array}{c}\text { Standardized } \\
\text { Coefficients }\end{array}$ & \multirow{2}{*}{ T } & \multirow{2}{*}{ Sig. } \\
\cline { 3 - 5 } & Bodel & $\begin{array}{c}\text { Std. } \\
\text { Error }\end{array}$ & Beta & & \\
\hline 1 & (Constant) & 2,308 & 7,702 & & 0,300 & 0,766 \\
\hline & Motivasi Kerja & 0,291 & 0,142 & 0,277 & 2,059 & 0,048 \\
\cline { 2 - 5 } & Lingkungan Kerja & 0,605 & 0,147 & 0,552 & 4,107 & 0,000 \\
\hline
\end{tabular}

a.Dependent Variable: KINERJA

Sumber: Output SPSS25 
Berdasarkan tabel yang ada diatas dapat dijelaskan pengaruh dari setiap variabel independen terhadap variabel dependen sebagai berikut:

\section{a. Variabel Motivasi}

Hipotesis

- H0: $\beta 10$ tidak ada pengaruh dan signifikan dari variabel Motivasi (X1) terhadap Kinerja (Y).

- Ha: $\beta 10$ ada pengaruh dan signifikan dari variabel Motivasi (X1) terhadap Kinerja (Y).

Hasil uji t untuk variabel Motivasi (X1) terhadap Kinerja (Y) menunjukan $\mathrm{t}$ hitung sebesar 2,059 sementara variabel ini dalam tabel distribusi 5\% t tabel sebesar 1,694. Hal ini berarti t hitung $(2,059)>t$ tabel 1,694$)$, dan memiliki nilai signifikansi sebesar $(0,048>0,05)$. Jadi bisa disimpulkan Ha: $\beta 1>0$ yang diterima dan $\mathrm{H} 0$ : $\beta 1<0$ ditolak. b. Variabel Lingkugan Kerja (X2) Hipotesis

- H0: $\beta 10$ tidak ada pengaruh dan signifikan dari variabel Lingkungan Kerja (X2) terhadap Kinerja (Y).

- Ha: $\beta 10$ ada pengaruh dan signifikan dari variabel Lingkungan Kerja (X2) terhadap Kinerja (Y).

Hasil uji t untuk variabel Lingkungan Kerja (X1), terhadap Kinerja (Y) menunjukan t hitung sebesar 4,107 sementara variabel ini dalam tabel distribusi 5\% t tabel sebesar 1,694. Hal ini berarti t hitung $(4,107)>$ dari t tabel $(1,694)$, dan memiliki signifikansi sebesar 0,000. Jadi bisa di simpulkan Jadi bisa disimpulkan Ha: $\beta 1 \neq 0$ yang diterima dan $\mathrm{H} 0$ : $\beta 1=0$ ditolak.

\section{Uji F}

Uji $F$ ini digunakan un tuk menunjukan apakah setiap variabel independent yang dimasukan kedalam model yang memiliki pengaruh simultan terhadap variabel dependen.

Tabel 12: uji F

\begin{tabular}{|l|c|c|c|c|c|c|}
\hline \multicolumn{2}{|c|}{ ANOVA $^{\mathbf{a}}$} \\
\hline \multirow{3}{*}{1} & Model & Sum of Squares & df & Mean Square & F & Sig. \\
\cline { 2 - 7 } & Regression & 161,518 & 2 & 80,759 & 14,105 & $.000^{\text {b }}$ \\
\cline { 2 - 7 } & Residual & 183,225 & 32 & 5,726 & & \\
\cline { 2 - 7 } & Total & 344,743 & 34 & & & \\
\hline
\end{tabular}

Sumber : Output SPSS25

Hipotesis:

- H0 diterima jika $\mathrm{F}$ hitung $<\mathrm{F}$ tabel pada $\alpha$ $=5 \%(0,05)$

- H1 diterima jika $\mathrm{F}$ hitung $>\mathrm{F}$ tabel pada $\alpha$ $=5 \%(0,05)$

Berdasarkan uji $\mathrm{F}$ dari tabel yang ada di atas ditunjukan $\mathrm{F}$ hitung sebesar 14,105 dan $\mathrm{f}$ tabel sebesar 3,29 dan berada pada taraf signifikansi $0,000<005$. Karena $\mathrm{F}$ hitung sebesar $(14,105)>$ dari $F$ Tabel $(3,29)$ dan berada pada signifikansi $0,000<0,05$ maka H1 diterima yang menjelaskan bahwa Motivasi (X1) dan Lingkungan Kerja (X2) berpengaruh secara simultan terhadap Kinerja (Y) Karyawan. 


\section{Pembahasan}

Penelitian ini bermaksud untuk mengetahui adanya pengaruh Motivasi (X1), Lingkungan Kerja (X2), terhadap Kinerja (Y) karyawan Bulog Kantor Cabang Makassar. Penelitian ini di peroleh dengan cara menyebarkan kuesioner kepada responden dan mengumpulkannya lagi. Penelitian ini menggunakan penguji analisis data dengan program SPSS versi 25.

1. Berdasarkan hasil uji parsial Motivasi (X1) terhadap Kinerja (Y) karyawan memperlihatkan jika $\mathrm{t}$ hitung $(2,059)>t$ tabel $(1,694)$ dan signifikansi sebesar $0,048>0,05$ hal ini dapat diartikan Motivasi (X1) berpengaruh tidak signifikan terhadap Kinerja (Y) karyawan pada Bulog Kantor Cabang Makassar, (Ho diterima). Pada penelitian ini apabila Motivasi (X1) tinggi maka akan berpengaruh terhadap Kinerja (Y) karyawan. Hal ini senada dengan penelitian Nurmin Arianto dan Hadi Kurniawan 2020, Pengaruh Motivasi Kerja dan Lingkungan Kerja Terhadap Kinerja Karyawan, juga sesuai dengan teori yang dikemukakan oleh Fahmi (2018:19) "bahwa salah satu cara untuk dapat mempertahankan kinerja yang baik dan menjauhkan karyawan dari timbulnya konflik adalah dengan selalu memberikan motivasi"

2. Berdasarkan hasil uji parsial Lingkungan (X2), terhadap Kinerja (Y) karyawan, memperlihatkan jika $\mathrm{t}$ hitung $(4,107)>\mathrm{t}$ tabel $(1,694)$ dan signifikansi sebesar $0,000<0,05$ hal ini dapat diartikan Lingkungan kerja (X2) memiliki pengaruh terhadap Kinerja (Y) karyawan pada Bulog Kantor Cabang Makassar. Hal ini senada dengan penelitian Muchamad Ressa Farizki 2017, Pengaruh Motivasi dan Lingkungan Kerja terhadap Kinerja Karyawan medis yang dimana Lingkungan kerja memiliki pengaruh yang signifikan terhadap Kinerja dan juga sesuai dengan teori yang dikemukakan oleh Sutrisno (2019:118-119) "lingkungan kerja yang buruk, kotor, gelap, pengap, lembab, dan sebagainya akan menimbulkan cepat lelah dan menurunkan kreativitas".

3. Berdasarkan uji $\mathrm{F}$ variable Motivasi (X1) dan Lingkungan Kerja (X2) berpengaruh secara simultan terhadap Kinerja (Y) Karyawan ditunjukan $\mathrm{F}$ hitung sebesar 14,105 dan f tabel sebesar 3,29 dan berada pada taraf signifikansi $0,000<005$. Karena F hitung sebesar $(14,105)>$ dari $F$ Tabel $(3,29)$ dan berada pada signifikansi $0,000<0,05$ maka $\mathrm{H} 1$ diterima yang menjelaskan bahwa.

4. Berdasarkan hasil uji analisis linear berganda antara variabel Motivasi (X1) dan Lingkungan Kerja (X2) terhadap Kinerja karyawan (Y) diperoleh hasil persamaan, $Y=2,308+0,291+0,605$

5. Hasil uji koofisien determinasi $\mathrm{R}$ square sebesar 0,469, artinya naik turunnya variabel dependen yaitu dalam penelitian ini Kinerja (Y) karyawan pada Bulog Kantor Cabang Makassar dipengaruhi oleh Variabel Motivasi (X1), dan Lingkungan Kerja (X2) sebesar 46,9\% sedangkan sisanya sebesar $53,1 \%$ dijellaskan oleh variabel lain diluar dari penelitian ini.

\section{PENUTUP}

\section{A. Kesimpulan}

Dari hasil penelitian variabel Motivasi dan Lingkungan kerja dengan reponden 35 orang dan 10 pernyataan tentang Motivasi diperoleh persentase sebesar $89,94 \%$ yang masuk kedalam kriteria sangat baik, dan juga 10 pernyataan tentang Lingkungan Kerja diperoleh persentase sebesar 86,63\% yanag masuk kedalam kriteria sangat baik. Pada variabel Kinerja hasil jawaban dari 35 responden dengan 10 pertanyaan/pernyataan tentang kinerja diperoleh persentase $86,12 \%$, bila dikaitkan dengan kriteria sebelumnya masuk kedalam kriteria sangat baik, dan 
berikut adalah kesimpulan dari pada penelitian ini:

1. Motivasi berpengaruh signifikan terhadap Kinerja karyawan pada Bulog Kantor Cabang Makassar. Hal ini dibuktikan dengan besarnya thitung $(2,059)<\mathrm{t}$ tabel $(1,694)$.

2. Lingkungan Kerja berpengaruh signifikan terhadap Kinerja karyawan pada bulog kantor cabang Makassar. Hal ini dibuktikan dengan besarnya thitung $(4,107)<t$ tabel $(1,694)$.

3. Motivasi dan lingkungan kerja berpengaruh secara simultan terhadap kinerja karyawan pada bulog kantor cabang Makassar. Hal ini dibuktikan dengan besarnya fhitung $(14,105)$ < ftabel $(3,29)$

4. Berdasarkan hasil uji analiss linear berganda antara variabel Motivasi (X1) dan Lingkungan Kerja (X2) terhadap Kinerja karyawan (Y) diperoleh hasil persamaan, $Y=2,308+0,291+0,605$.

5. Hasil uji koofisien determinasi R square sebesar 0,469 artinya naik turunnya variabel dependen yaitu dalam penelitian ini Kinerja (Y) karyawan pada Bulog Kantor Cabang Makassar dipengaruhi oleh Variabel Motivasi (X1), dan Lingkungan Kerja (X2) sebesar 46,9\% sedangkan sisanya sebesar $53,1 \%$ dijelaskan oleh variabel lain diluar dari penelitian ini.

\section{B. Saran}

Berdasarkan hasil penelitian yang telah dilakukan, peneliti dapat mengajukan beberapa saran sebagai berikut:

1. Motivasi pada bulog kantor cabang Makasar sudah baik, hanya perlu mempertahankan faktor yang paling mempengaruhi ialah pengakuan dari atasan dimana perusahaan dapat mempertahanan kebiasaan memberikan pujian kepada karyawan yang telah mampu menyelesaikan pekerjaan yang diberikan dengan hasil yang memuaskan.

2. Lingkungan kerja yang ada sudah baik jadi hanya perlu mempertahankan faktor yang paling mempengaruhi ialah keberadaan satpam, dimana perusahaan diharapkan dapat meningkatkan keamanan ruang lingkup perusahaan agar para karyawan merasa aman dan nyaman dalam bekerja yang nantinya akan meningkatkan kinerja karyawan.

3. Kinerja karyawan pada bulog kantor cabang Makassar sudah cukup baik namun perlu ditingkatkan dibagian pekerjaan yang selalu mendekati titik kesempurnaan, dan juga penekanan biaya yang dilakukan guna meningkatkan kinerja yang sudah baik tersebut.

4. Perusahaan diharapkan mampu mempertahankan dan meningkatkan semua kegiatan yang mana dapat memacu peningkatan kinerja dari para karyawan, seperti kebiasaan memberikan pujian,menjaga hubungan baik antar karyawan dan juga pimpinan, juga keamanan ruang lingkup perusahaan. 


\section{DAFTAR PUSTAKA}

Afandi, Pandi. 2016. Concept \& Indicator Human Resources Management For Managenment Reseacth. Deepublish, Yogyakarta

. 2018. Manajemen Sumber Daya Manusia Teori, Konsep dan Indikator. Zanafa Publishing, Pekan Baru.

Bangun, Wilson. 2012. Manajemen Sumber Daya Manusia. Erlangga, Jakarta.

Busro, Muhammad. 2020. Teori-Teori Manajemen Sumber Daya Manusia. Prenanamedia, Jakarta.

Eka Wilda, Faida. 2019. Manajemen Sumber

Daya Manusia dan Erkogonomi unit Rekam Kerja Medis. Indonesia Pustaka, Sidoarjo.

Fahmi, Irham. 2016. Manajemen Sumber Daya

Manusia Teori dan Aplikasi. Alfabeta, Bandung.

Fatullah, Jurdi. 2016. Manajemen Sumber

Daya Manusia Pengelolaan SDM

Berkualitas dan Berdaya Saing Instasi

Publishing, Malang.

Hasibuan, Malayu. 2016. Manajemen Sumber

Daya Manusia. Bumi Aksara, Jakarta.

. 2020. Manajemen Sumber Daya

Manusia Edisi Revisi. Bumi Akasara, Jakarta.

Kasmir. 2019. Manajemen Sumber Daya Manusia Teori dan Praktik. PT. Rajagrafindo Persada, Depok.

Lijan Poltak, Sinambela. 2018. Manajemen Sumber Daya Manusia. PT. Bumi Aksara, Jakarta.

Mangkunegara. 2017. Manajemen Sumber

Daya Manusia Perusahaan. PT. Remaja Rosda Karya, Bandung.
Martoyo, Susilo. 2015. Manajemen Sumber Daya Manusia. BPFE UGM Yogyakarta.

Nawawi, Handar. 2016. Manajemen Sumber Daya Manusia untuk Bisnis yang Kompetitif. Gajah Mada University Press, Yogyakarta

Rivai. 2015. Manajemen Sumber Daya Manusia untuk Perusahaan. Rajawali Pers, Jakarta.

Sedarmayanti. 2017. Perencanaan dan Pengembangan Sumber Daya Manusia untuk Meningkatkan Kompetensi, Kinerja dan Produktivitas Kerja. PT. Refika Aditama, Bandung.

Siagian P, Sondang. 2014. Manajemen Sumber Daya Manusia. Bumi Aksara, Jakarta.

Sudaryo, Y., Ariwibowo, A.,dan Sofiati, N. 2018. Manajemen Sumber Daya Manusia. Penerbit Andi, Yogyakarta.

Sugiyono. 2017. Metode Penelitian Kuantitatif, Kualitatif dan R\&D. Yogyajarta 55167. . 2018. Metode Penelitian Kuantitatif, Kualitatif, dan R\&D. Alfabeta, Bandung.

Sunyoto, Danang. 2015. Manajemen dan Pengembangan Sumber Daya Manusia Cetakan Pertama. CAPS (Center For Academic Publishing Center), Yogyakarta.

Sutrisno, Edy. 2019. Manajemen Sumber Daya Manusia. Prenadamedia Group, Jakarta. Suyadi, P., dan Dewi, P. 2017. Manajemen Sumber Daya Manusia Kinerja, Motivasi, dan Etos Kerja Karyawan Edisi keempat. BPFE Yogyakarta.

Wibowo. 2017. Manajemen Kinerja Edisi Ke

Lima. PT. Rajagrafindo Persada, Depok. 
Widodo, S., dan Sukoco., I. 2016. Manajemen Sumber Daya Manusia Teori, Studi Kasus, Motivasi, dan Internasionalisasi.
Manggu Makmur Tanjung Lestari, Bandung. 